\title{
Enhanced Bioavailability of Glimepiride in the Presence of Boswellic Acids in Streptozotocin-Induced Diabetic Rat Model
}

\author{
Sujatha Samala* and Ciddi Veeresham \\ University College of Pharmaceutical Sciences, Kakatiya University, Warangal, AP-506009, India
}

\begin{abstract}
The effect of Boswellia serrata standardized extract (BSE) and Boswellic acids (BA) on the pharmacokinetics and pharmacodynamics of glimepiride in normal as well as diabetic rats was studied. In normal and streptozotocin induced diabetic rats the combination of glimepiride with BSE and BA increased all the pharmacokinetic parameters, such as Cmax, AUC0-n, AUCtotal, $t 1 / 2$, MRT and decreased the clearance, Vd markedly as compared with the control group. In pharmacodynamic studies, the combination of glimepiride with BSE and BA provided significant protection against the diabetes induced alterations in the biochemical parameters. In addition, the combination of glimepiride with BSE and $\mathrm{BA}$ also improved the total antioxidant status and reduced the lipid peroxide levels significantly in diabetic rats compared with BSE, BA and glimepiride alone treated groups. The results revealed that a combination of glimepiride with BSE and BA led to the enhancement of the bioavailability of glimepiride by inhibiting the CYP2C9 enzyme, which suggested that boswellia might be beneficial as an adjuvant to glimepiride in a proper dose, in diabetic patients.
\end{abstract}

Keywords: CYP2C9; Boswellia serrata standardized extract; Boswellic acids; Glimepiride; Pharmacokinetics; Pharmacodynamics

\section{Introduction}

The use of herbal medicine as alternative and/or complementary therapy in the western world is on the rise and gaining increasing popularity. As people often take different herbs in combination with prescribed modern medication, there is a potential for both pharmacokinetic and pharmacodynamic interaction [1]. However, it has been reported that herbal products containing a number of natural compounds can cause pharmacokinetic and pharmacodynamic interaction with modern drugs when they were administrated simultaneously [2,3]. Glimepiride, a sulphonylurea used as an oral hypoglycemic agent, is widely used for the treatment of type 2 diabetes mellitus. The hypoglycemic effect of glimepiride was changed during co-administration with Carica papaya extract [4], thus there is a need to study the interaction between glimepiride and other drugs to avoid adverse effects. In addition, people with diabetes are likely to select alternative therapy, including herbal medicine, to treat diabetes. For these reasons, BSE or BA might be used together with antidiabetic drugs.

Boswellia serrata, known as sallaki or salai guggal or frankincense, is widely used in India to treat various types of blood disorders, inflammatory health ailments, pain and cardiac debility [5]. The 6 major active components in B. serrata are $\alpha$-Boswellic acid, $\beta$-Boswellic acid, 3-Acetyl- $\alpha$-Boswellic acid, 3-Acetyl- $\beta$-Boswellic acid, 11-keto$\beta$-Boswellic acid and 3-Acetyl-11-keto- $\beta$-Boswellic acid. Many studies have shown that $B$. serrata and its major component, BA have various pharmacological activities, such as anti-inflammatory [6], anticancer [7], anti-arthritic [8], immunomodulatory [9], antidiabetic [10] and analgesic [11].

There are several in vitro reports of BSE or BA on inhibition of microsomal enzyme system (CYP1A2, 2C8, 2C9, 2D6 and 3A4) and may lead to change in the bioavailability of concomitant drugs [12]. Hence, there is the possibility of BSE or BA for the metabolic inhibition of glimepiride, which is also completely metabolized by CYP2C9 microsomal liver enzymes [13].

In view of the effect of BSE or BA on CYP enzymes especially on CYP2C9 and also antidiabetic property, its presence in herbal antidiabetic preparations may influence the bioavailability of glimepiride, particularly because the later is metabolized by CYP2C9.
Therefore, the aim of the present investigation was to study the effect of BSE or BA on bioavailability and pharmacodynamics of glimepiride.

\section{Experimental}

\section{Drugs and chemicals}

Glimepiride and gliclazide were obtained as gift samples from Dr. Reddy's laboratories (Hyderabad, India). Methanol (HPLC-grade), potassium dihydrogen orthophosphate and orthophosphoric acid of AR grade (99.5\%) were procured from Merck Specialties Pvt. Ltd., Mumbai. Boswellic acid (BA) was purchased from Yucca Enterprises, Mumbai. Boswellia serrata standardized extract (BSE) was obtained as gift sample from Amsar Pvt. Ltd., Indore. Ascorbic acid, $\alpha$, $\alpha$-diphenyl$\beta$-picrylhydrazyl (DPPH), 1,1,3,3-tetraethoxy propane (TEP), thiobarbituric acid and streptozotocin (STZ) were purchased from Hi Media Laboratories Pvt. Ltd, Mumbai. Merck analytical kits were used to estimate the serum biochemical parameters. Water for analytical purpose is double distilled, filtered by using direct-Quv millipore and sonicated for removing air bubbles. All other chemicals used were of analytical grade.

\section{Maintenance of animals}

Male Albino rats of Wistar strain weighing 180-250 g were purchased from Mahaveera enterprises, Hyderabad, India and used for the studies after obtaining the permission from institutional animal ethical committee (CPCSEA Reg. No.146/1999). The animals were housed in standard polypropylene cages and maintained under standard laboratory conditions (12:12 h light and dark cycle; at an ambient temperature of $25 \pm 5^{\circ} \mathrm{C} ; 35-60 \%$ of relative humidity). The animals were fed with standard rat pellet diet and water ad libitum.

*Corresponding author: Sujatha Samala, University College of Pharmaceutica Sciences, Kakatiya University, Warangal, AP-506009, India, E-mail: sujathasamala@gmail.com

Received September 11, 2013; Accepted September 23, 2013; Published September 30, 2013

Citation: Samala S, Veeresham C (2013) Enhanced Bioavailability of Glimepiride in the Presence of Boswellic Acids in Streptozotocin-Induced Diabetic Rat Model. Nat Prod Chem Res 1: 116 doi:10.4172/ 2329-6836.1000116

Copyright: $\odot 2013$ Samala S, et al. This is an open-access article distributed under the terms of the Creative Commons Attribution License, which permits unrestricted use, distribution, and reproduction in any medium, provided the original author and source are credited. 


\section{Pharmacokinetic study}

Grouping of normal rats and pretreatment: Rats were divided into 3 groups $(n=6)$. Group I was administered with glimepiride (1 $\mathrm{mg} / \mathrm{kg}$; b.w., p.o.) suspended in normal saline on $8^{\text {th }}$ day. Group II was pretreated with BSE $(200 \mathrm{mg} / \mathrm{kg}$; b.w., p.o. $)$ for 7 days and on $8^{\text {th }}$ day with glimepiride $(1 \mathrm{mg} / \mathrm{kg})$ followed by BSE and group III was pretreated with BA $\left(100 \mathrm{mg} / \mathrm{kg}\right.$; b.w., p.o.) for 7 days and on $8^{\text {th }}$ day with glimepiride $(1 \mathrm{mg} / \mathrm{kg})$ followed by BA. Before the collection of blood samples animals were fasted for $16 \mathrm{~h}$ with water ad libitum. Blood samples were collected from retro-orbital vein puncture [14] using heparinised capillary tubes at $0.5,1,2,4,6,8,12$ and $24 \mathrm{~h}$. Serum was separated after centrifugation at $8000 \mathrm{rpm}$ for $15 \mathrm{~min}$ and stored at $-20^{\circ} \mathrm{C}$ until analysis.

Induction of diabetes in rats: Diabetes was induced by using streptozotocin $(55 \mathrm{mg} / \mathrm{kg}$, b.w., i.p.) in citrate buffer ( $\mathrm{pH} 4.5)$ to the overnight fasted Wistar rats [15]. After $72 \mathrm{~h}$, blood samples were collected from rats by retro orbital puncture and the serum was analyzed for glucose levels. Animals with blood glucose level $>250 \mathrm{mg} /$ $\mathrm{dl}$ were considered as diabetic and were used for the study.

Grouping of diabetic rats and treatment: Diabetic rats were divided into 3 groups $(n=6)$ and were treated; blood samples were collected as mentioned for normal rats.

HPLC analysis of glimepiride in normal and diabetic pretreated rats: Serum glimepiride concentration was determined by reverse phase HPLC [16]. The solvent delivery system was a shimadzu pump model LC-10AT (Shimadzu, Japan) and the analytical column used was Lichrosphere $100 \mathrm{RP} \mathrm{C}_{18}(125 \times 4.0 \mathrm{~mm}$ i.d, $5 \mu$ particle size $)$. Column effluent was monitored with SPD-M10Avp diode array detector at $230 \mathrm{~nm}$. The HPLC system was equilibrated with the mobile phase consisting of methanol: $10 \mathrm{~mm}$ potassium dihydrogen ortho phosphate (pH 3.0 adjusted with ortho phosphoric acid) $(80: 20 \mathrm{v} / \mathrm{v})$, at a flow rate of $1.0 \mathrm{ml} / \mathrm{min}$. Serum samples were denatured by methanol and then centrifuged at $8000 \mathrm{rpm}$ for $15 \mathrm{~min} .20 \mu \mathrm{l}$ of clear supernatant was injected into the HPLC system for quantitation.

\section{Pharmacodynamic studies}

Effect of BSE and BA with glimepiride on serum glucose in STZ-induced diabetic rats: TZ-induced diabetic rats were fasted overnight and divided into 6 groups $(n=6)$. The animals of group I (diabetic control, normal saline), group II (glimepiride, $1 \mathrm{mg} / \mathrm{kg}$ ), group III (BSE, $200 \mathrm{mg} / \mathrm{kg}$ ), group IV (BA, $100 \mathrm{mg} / \mathrm{kg}$ ), group V [BSE $(200 \mathrm{mg} / \mathrm{kg})+$ glimepiride $(1 \mathrm{mg} / \mathrm{kg})]$ and group VI [BA $(100$ $\mathrm{mg} / \mathrm{kg})+$ glimepiride $(1 \mathrm{mg} / \mathrm{kg})]$ were treated orally with the material mentioned in the parenthesis of the respective group. The effect of the BSE, BA, glimepiride alone and their combinations on fasting blood glucose level was studied up to $24 \mathrm{~h}$. Blood samples were drawn from the retro-orbital plexus of the rats at ' 0 ' (Initial fasting blood sample), 2, $4,6,8,12$ and $24 \mathrm{~h}$ after the treatment. The samples were analyzed for blood glucose using glucose oxidase-peroxidase method [17].

Oral glucose tolerance test (OGTT) in STZ-induced diabetic rats: The diabetic overnight fasted rats were divided into 6 groups $(n=6)$ and treated same as mentioned in above study. The rats of all the groups were loaded with D-glucose $(2.5 \mathrm{~g} / \mathrm{kg}$, p.o $) 30$ minutes after the treatment [3]. Blood samples were collected from the rats at 30,60 , 90 and 120 minutes after glucose loading for determination of blood glucose levels.

Assessment of different biochemical parameters in STZ-induced diabetic rats: Overnight fasted STZ-induced diabetic rats were divided into 6 groups (I-VI) same as mentioned in above study and they were treated once a day for 28 days (sub acute study) and their body weight, fasting blood glucose level, serum insulin, serum glutamate oxaloacetate transaminase (SGOT), serum glutamate pyruvate transaminase (SGPT), serum cholesterol, serum triglyceride and serum total proteins were estimated [18]. During the study period, the body weight of the animals and blood glucose levels were recorded after 7, 14, 21 and 28 days of the treatment. Serum insulin, SGOT, SGPT, serum cholesterol, serum triglyceride and serum total protein levels were estimated after 28 days of the treatment.

Estimation of total antioxidant status in diabetic pretreated rats: The serum samples of sub acute study were used to determine the total antioxidant status by using DPPH method [19]. Ascorbic acid was used as a reference standard. The standard graph was prepared using different concentrations of ascorbic acid in water $(y=0.0018 x+0.0116$, $\mathrm{r}=0.9953$ ) and the antioxidant status values were expressed in terms of $\mathrm{nM}$ of ascorbic acid.

Estimation of lipid peroxide levels in diabetic pretreated rats: The serum samples of sub acute study were used to determine the lipid peroxides by using thiobarbituric acid reaction method [20]. The standard graph for determination of malondialdehyde levels was prepared using 1,1,3,3 - tetraethoxy propane (TEP) reagent as the standard ( $\mathrm{y}=0.075 \mathrm{x}-0.0368, \mathrm{r}=0.9989)$ and the MDA content in the serum was expressed in $\mathrm{nM} / \mathrm{ml}$.

Statistical analysis: All values of pharmacokinetic and pharmacodynamic studies were expressed as mean \pm SD. The data were statistically evaluated using one way analysis of variance (ANOVA) followed by post hoc Dunnet's t-multiple comparison tests using Graph Pad Prism 4 computer software. Values corresponding to $p \leq 0.05$ were considered as significant.

\section{Results and Discussion}

The results of pharmacokinetic study in normal rats found that the $\mathrm{C}_{\max }$ of glimepiride significantly increased in coadministration of BSE and $\mathrm{BA}$ (1.29 times, 1.45 times), $\mathrm{AUC}_{0-\mathrm{n}}$ (1.40 times, 1.68 times), $\mathrm{AUC}_{\text {total }}$ (1.41 times, 1.70 times), $\mathrm{t}_{1 / 2}$ (1.02 times, 1.14 times), MRT (1.07 times, 1.08 times), whereas the clearance ( 0.86 times, 0.81 times)and volume

\begin{tabular}{|l|l|l|l|}
\hline PK parameter & Glimepiride & Glimepiride+BSE & limepiride+BA \\
\hline $\mathrm{C}_{\max }(\mu \mathrm{g} / \mathrm{ml})$ & $7.45 \pm 0.11$ & $9.66 \pm 0.26^{* *}$ & $10.78 \pm 0.58^{* *}$ \\
\hline $\mathrm{T}_{\max }(\mathrm{h})$ & 2 & 2 & 2 \\
\hline $\mathrm{AUC}_{0-\mathrm{n}}(\mu \mathrm{g} / \mathrm{ml} \mathrm{h})$ & $24.36 \pm 0.67$ & $34.13 \pm 0.61^{* *}$ & $40.97 \pm 1.25^{\star *}$ \\
\hline $\mathrm{AUC}_{\text {tot }}(\mu \mathrm{g} / \mathrm{ml} \mathrm{h})$ & $24.63 \pm 0.72$ & $34.64 \pm 0.69^{\star *}$ & $41.78 \pm 1.21^{* *}$ \\
\hline $\mathrm{t} 1 / 2(\mathrm{~h})$ & $1.63 \pm 0.21$ & $1.67 \pm 0.10$ & $1.86 \pm 0.13^{*}$ \\
\hline $\mathrm{MRT}(\mathrm{h})$ & $3.82 \pm 0.08$ & $4.08 \pm 0.06^{* *}$ & $4.14 \pm 0.05^{\star *}$ \\
\hline $\mathrm{tCL}(\mathrm{ml} / \mathrm{min})$ & $155.9 \pm 2.35$ & $134.2 \pm 5.6^{\star *}$ & $126.5 \pm 4.9^{* *}$ \\
\hline $\mathrm{Vd}(\mathrm{ml})$ & $52.5 \pm 7.56$ & $43.7 \pm 2.8^{* *}$ & $35.6 \pm 3.4^{* *}$ \\
\hline
\end{tabular}

All values are expressed as mean $\pm S D(n=6)$.

${ }^{*} p<0.05 ;{ }^{* *} p<0.01$ considered as significant when compared with glimepiride control

aDefinitions of the parameters:

$\mathbf{C}_{\max }$ : Peak serum concentration;

$T_{\text {max }}^{\text {max }}$ : Time to reach peak serum concentration;

AUC $C_{0 \text { : }}$ Area under serum concentration/time plot until the last quantifiable value;

$\mathrm{AUC}_{\text {total }}$ : Area under serum concentration/time plot extrapolated to infinity;

$\mathbf{t}_{1 / 2}:$ Terminal half life;

MRT: Average mean residence time;

CL: Total clearance;

Vd: Volume of distribution

Table 1: Mean pharmacokinetic parameters of glimepiride in different groups of normal rats. 
Citation: Samala S, Veeresham C (2013) Enhanced Bioavailability of Glimepiride in the Presence of Boswellic Acids in Streptozotocin-Induced Diabetic Rat Model. Nat Prod Chem Res 1: 116 doi:10.4172/ 2329-6836.1000116

Page 3 of 6

\begin{tabular}{|c|c|c|c|}
\hline PK parameter ${ }^{\mathrm{a}}$ & Glimepiride & Glimepiride+BSE & limepiride+BA \\
\hline $\mathrm{C}_{\max }(\mu \mathrm{g} / \mathrm{ml})$ & $11.33 \pm 0.36$ & $34.68 \pm 2.84^{* *}$ & $34.83 \pm 0.64^{* *}$ \\
\hline $\mathrm{T}_{\max }(\mathrm{h})$ & 2 & 22 & 2 \\
\hline$A \cup C_{0-n}(\mu \mathrm{g} / \mathrm{ml} \mathrm{h})$ & $51.07 \pm 2.13$ & $163.83 \pm 3.26^{* *}$ & $182.51 \pm 6.95^{* *}$ \\
\hline$A \cup C_{\text {tot }}(\mu \mathrm{g} / \mathrm{ml} \mathrm{h})$ & $51.83 \pm 2.08$ & $194.19 \pm 3.91^{* *}$ & $240.73 \pm 7.53^{* *}$ \\
\hline$t 1 / 2(h)$ & $1.69 \pm 0.25$ & $4.72 \pm 0.04^{* *}$ & $5.65 \pm 0.52^{* *}$ \\
\hline MRT (h) & $3.95 \pm 0.09$ & $7.12 \pm 0.02^{* *}$ & $8.62 \pm 0.69^{* *}$ \\
\hline $\mathrm{tCL}(\mathrm{ml} / \mathrm{min})$ & $125.6 \pm 2.35$ & $92.4 \pm 2.1^{* *}$ & $78.3 \pm 4.6^{* *}$ \\
\hline $\mathrm{Vd}(\mathrm{ml})$ & $36.2 \pm 7.56$ & $21.2 \pm 2.4^{* *}$ & $15.8 \pm 1.7^{\star *}$ \\
\hline
\end{tabular}

All values are expressed as mean $\pm S D(n=6)$.

${ }^{*} p<0.05 ;{ }^{* *} p<0.01$ considered as significant when compared with glimepiride control

aDefinitions of the parameters:

$\mathrm{C}_{\text {max }}$ : Peak serum concentration;

$\mathbf{T}_{\max }$ : Time to reach peak serum concentration;

AUC : Area under serum concentration/time plot until the last quantifiable value;

$\mathrm{AUC}_{\text {total }}$ : Area under serum concentration/time plot extrapolated to infinity;

$\mathbf{t}_{1 / 2}$ : Terminal half life;

MRT: Average mean residence time;

CL: Total clearance

Vd: Volume of distribution

Table 2: Mean pharmacokinetic parameters of glimepiride in different groups of STZ-induced diabetic rats.

\begin{tabular}{|c|c|c|c|c|c|c|c|c|c|}
\hline \multirow[t]{2}{*}{ Group no } & \multirow[t]{2}{*}{ Treatment } & \multirow[t]{2}{*}{ Dose (mg/kg) } & \multicolumn{7}{|c|}{ Blood glucose level (mg/dl) at different hours } \\
\hline & & & $\mathbf{O h}$ & $2 \mathrm{~h}$ & $4 \mathrm{~h}$ & $6 \mathrm{~h}$ & $8 \mathrm{~h}$ & $12 \mathrm{~h}$ & $24 \mathrm{~h}$ \\
\hline I & Control & --- & $334.52 \pm 1.64$ & $\begin{array}{c}332.85 \pm 1.61 \\
(0.49 \%)\end{array}$ & $\begin{array}{c}332.28 \pm 1.42 \\
(0.66 \%)\end{array}$ & $\begin{array}{c}331.23 \pm 1.17 \\
(0.98 \%)\end{array}$ & $\begin{array}{c}332.7 \pm 1.10 \\
(0.54 \%)\end{array}$ & $\begin{array}{c}333.2 \pm 1.23 \\
(0.39 \%)\end{array}$ & $\begin{array}{c}334.27 \pm 1.76 \\
(0.07 \%)\end{array}$ \\
\hline II & Glimepiride & $1 \mathrm{mg} / \mathrm{kg}$ & $342.53 \pm 2.4$ & $\begin{array}{c}281.6 \pm 3.91 \\
(17.79 \%)^{\star *}\end{array}$ & $\begin{array}{c}226.32 \pm 4.56 \\
(33.93 \%)^{\star *}\end{array}$ & $\begin{array}{c}171.02 \pm 4.88 \\
(50.07 \%)^{\star *}\end{array}$ & $\begin{array}{c}255.13 \pm 11.3 \\
(25.52 \%)^{* *}\end{array}$ & $\begin{array}{c}291.55 \pm 4.91 \\
(14.88 \%)^{* *}\end{array}$ & $\begin{array}{c}331.05 \pm 1.03 \\
(3.35 \%)^{*}\end{array}$ \\
\hline II & BSE & $200 \mathrm{mg} / \mathrm{kg}$ & $320.4 \pm 5.1$ & $\begin{array}{r}273.8 \pm 5.8 \\
(14.54 \%)^{\star *}\end{array}$ & $\begin{array}{l}235.4 \pm 3.2 \\
(26.53 \%)^{\star *}\end{array}$ & $\begin{array}{c}209.3 \pm 4.9 \\
(34.66 \%)^{\star *}\end{array}$ & $\begin{array}{l}242.7 \pm 6.8 \\
(24.25 \%)^{\star *}\end{array}$ & $\begin{array}{l}278.2 \pm 4.5 \\
(13.17 \%)^{\star *}\end{array}$ & $\begin{array}{c}316.3 \pm 8.4 \\
(0.01 \%)^{\star}\end{array}$ \\
\hline IV & BA & $100 \mathrm{mg} / \mathrm{kg}$ & $325.2 \pm 3.8$ & $\begin{array}{c}281.3 \pm 8.3 \\
(13.5 \%)^{* \star}\end{array}$ & $\begin{array}{c}240.6 \pm 7.5 \\
(26.01 \%)^{\star *}\end{array}$ & $\begin{array}{l}210.1 \pm 7.2 \\
(35.39 \%)^{\star *}\end{array}$ & $\begin{array}{l}245.2 \pm 9.2 \\
(24.60 \%)^{\star *}\end{array}$ & $\begin{array}{c}275.1 \pm 7.3 \\
(15.41 \%)^{* *}\end{array}$ & $\begin{array}{c}322.5 \pm 5.1 \\
(0.01 \%)^{*}\end{array}$ \\
\hline $\mathbf{V}$ & BSE+Glimepiride & $\begin{array}{l}200 \mathrm{mg} / \mathrm{kg}+1 \\
\mathrm{mg} / \mathrm{kg}\end{array}$ & $351.1 \pm 4.6$ & $\begin{array}{l}292.1 \pm 7.7 \\
(16.80 \%)^{* *}\end{array}$ & $\begin{array}{l}233.8 \pm 6.3 \\
(33.41 \%)^{* *}\end{array}$ & $\begin{array}{l}165.2 \pm 5.8 \\
(52.95 \%)^{* *}\end{array}$ & $\begin{array}{l}213.6 \pm 3.1 \\
(39.16 \%)^{* *}\end{array}$ & $\begin{array}{l}268.4 \pm 5.4 \\
(23.55 \%)^{* *}\end{array}$ & $\begin{array}{c}294.1 \pm 4.6 \\
(16.23 \%)^{* *}\end{array}$ \\
\hline VI & BA+Glimepiride & $\begin{array}{l}100 \mathrm{mg} / \mathrm{kg}+1 \\
\mathrm{mg} / \mathrm{kg}\end{array}$ & $360.8 \pm 6.2$ & $\begin{array}{l}295.8 \pm 6.5 \\
(18.02 \%)^{\star *}\end{array}$ & $\begin{array}{l}228.6 \pm 8.8 \\
(36.64 \%)^{\star *}\end{array}$ & $\begin{array}{l}169.4 \pm 4.7 \\
(53.04 \%)^{\star *}\end{array}$ & $\begin{array}{c}208.3 \pm 5.6 \\
(42.27 \%)^{\star *}\end{array}$ & $\begin{array}{l}243.5 \pm 6.7 \\
(32.51 \%)^{\star *}\end{array}$ & $\begin{array}{l}286.2 \pm 7.1 \\
(20.68 \%)^{\star *}\end{array}$ \\
\hline
\end{tabular}

All values are expressed as mean $\pm S D(n=6)$

${ }^{*} p<0.05 ;{ }^{* *} p<0.01$ considered as significant when compared with Group I at respective time interval

Table 3: Comparison of mean serum glucose levels and percentage reduction of serum glucose level of Group II, Group III Group IV, Group V and Group VI with Group I in STZ-induced diabetic rats.

\begin{tabular}{|c|c|c|c|c|c|c|c|}
\hline \multirow[t]{2}{*}{ Group No } & \multirow[t]{2}{*}{ Treatment } & \multirow[t]{2}{*}{ Dose (mg/kg) } & \multicolumn{5}{|c|}{ Blood glucose levels (mg/dl) at different time intervals } \\
\hline & & & $0 \mathrm{~min}$ & $30 \mathrm{~min}$ & $60 \mathrm{~min}$ & $90 \mathrm{~min}$ & $120 \mathrm{~min}$ \\
\hline 1 & Control & - & $424.43 \pm 2.57$ & $\begin{array}{c}415.72 \pm 3.23 \\
2.05 \%\end{array}$ & $\begin{array}{c}397.35 \pm 4.67 \\
6.30 \%\end{array}$ & $\begin{array}{c}382.60 \pm 2.47 \\
9.86 \%\end{array}$ & $\begin{array}{c}367.9 \pm 2.26 \\
13.32 \%\end{array}$ \\
\hline II & Glimepiride & $1 \mathrm{mg} / \mathrm{kg}$ & $403.67 \pm 2.49$ & $\begin{array}{c}364.47 \pm 2.52 \\
(9.71 \%)^{* *}\end{array}$ & $\begin{array}{c}333.22 \pm 2.0 \\
(17.45 \%)^{\star *}\end{array}$ & $\begin{array}{c}278.70 \pm 2.67 \\
(30.96 \%)^{* *}\end{array}$ & $\begin{array}{c}241.63 \pm 2.13 \\
(40.14 \%)^{\star *}\end{array}$ \\
\hline III & BSE & $200 \mathrm{mg} / \mathrm{kg}$ & $385.2 \pm 6.7$ & $\begin{array}{l}342.5 \pm 4.2 \\
(11.09 \%)^{\star *}\end{array}$ & $\begin{array}{l}300.1 \pm 7.8 \\
(22.09 \%)^{\star *}\end{array}$ & $\begin{array}{l}273.4 \pm 6.9 \\
(29.02 \%)^{* *}\end{array}$ & $\begin{array}{l}255.5 \pm 6.3 \\
(33.67 \%)^{\star \star}\end{array}$ \\
\hline IV & BA & $100 \mathrm{mg} / \mathrm{kg}$ & $390.1 \pm 4.8$ & $\begin{array}{c}353.7 \pm 7.8 \\
(9.33 \%)^{\star *}\end{array}$ & $\begin{array}{l}311.2 \pm 9.5 \\
(20.23 \%)^{\star *}\end{array}$ & $\begin{array}{l}284.6 \pm 4.5 \\
(27.04 \%)^{\star *}\end{array}$ & $\begin{array}{l}252.3 \pm 7.2 \\
(35.32 \%)^{\star *}\end{array}$ \\
\hline $\mathrm{V}$ & BSE+Glimepiride & $\begin{array}{l}200 \mathrm{mg} / \mathrm{kg} \\
+1 \mathrm{mg} / \mathrm{kg}\end{array}$ & $420.4 \pm 9.4$ & $\begin{array}{l}361.3 \pm 6.4 \\
(14.05 \%)^{\star *}\end{array}$ & $\begin{array}{l}316.4 \pm 5.7 \\
(24.74 \%)^{\star *}\end{array}$ & $\begin{array}{c}276.2 \pm 7.4 \\
(34.3 \%)^{\star *}\end{array}$ & $\begin{array}{l}240.6 \pm 4.1 \\
(42.77 \%)^{\star *}\end{array}$ \\
\hline $\mathrm{VI}$ & BA+Glimepiride & $\begin{array}{l}100 \mathrm{mg} / \mathrm{kg} \\
+1 \mathrm{mg} / \mathrm{kg}\end{array}$ & $430.7 \pm 8.3$ & $\begin{array}{c}388.2 \pm 9.1 \\
(9.87 \%)^{\star *}\end{array}$ & $\begin{array}{l}335.6 \pm 4.3 \\
(22.08 \%)^{\star *}\end{array}$ & $\begin{array}{c}291.1 \pm 3.6 \\
32.41 \%\end{array}$ & $\begin{array}{l}245.1 \pm 8.4 \\
(43.09 \%)^{\star *}\end{array}$ \\
\hline
\end{tabular}

All values are expressed as mean $\pm \operatorname{SD}(n=6)$

${ }^{*} \mathrm{p}<0.05 ;{ }^{* *} \mathrm{p}<0.01$ considered as significant when compared with Group I at respective time interval

Table 4: Comparison of oral glucose tolerance and percentage reduction of serum glucose level of Group II, Group III, Group IV, Group V and Group VI with Group I in STZ-induced diabetic rats.

of distribution (0.83 times, 0.68 times) of glimepiride was decreased, when compared with control group. Mean pharmacokinetic parameters of glimepiride in different groups of normal rats are shown in Table 1. In STZ-induced diabetic rats the $\mathrm{C}_{\max }$ of glimepiride significantly increased in coadministration of BSE and BA (3.06 times, 3.07 times), $\mathrm{AUC}_{0 \text {-n }}$ (3.21 times, 3.57 times), $\mathrm{AUC}_{\text {total }}$ (3.75 times, 4.64 times), $\mathrm{t}_{1 / 2}$ (2.79 times, 3.34 times), MRT (1.80 times, 2.18 times), whereas the clearance ( 0.74 times, 0.62 times)and volume of distribution (0.59 times, 0.44 times) of glimepiride was decreased, when compared with control group. The $\mathrm{T}_{\max }$ of glimepiride in both normal and diabetic groups was not altered by concurrent administration with BSE and BA. Mean pharmacokinetic parameters of glimepiride in different groups of diabetic rats were depicted in Table 2 . 
In normal and STZ-induced diabetic rats combination of glimepiride with BSE and BA there is a significant increase in pharmacokinetic parameters such as $\mathrm{C}_{\max }, \mathrm{AUC}_{0-\mathrm{n}}, \mathrm{AUC}_{\text {total }}, \mathrm{t}_{1 / 2}$ and MRT. This may be due to alteration in the metabolism of glimepiride either by enhancing absorption or by inhibiting CYP2C9 responsible for glimepiride metabolism. In BSE or BA treated group there is no change in $\mathrm{T}_{\max }$ of glimepiride in both normal and diabetic rats indicating that there is no alteration in rate of absorption of glimepiride and the serum affinity of glimepiride for albumin is $99.5 \%$ bound. Acidic drugs can displace ionic binding of sulfonylureas from serum proteins to far greater extent than the non-ionic bound glimepiride. This indicates that the decreased volume of distribution is may not be due to displacement of glimepiride by BSE or BA. As there is no plasma protein binding interactions in between BSE or BA with glimepiride, so the decreased volume of distribution may be due to metabolic inhibition of glimepiride by BSE or BA. This metabolic inhibition decreases metabolic clearance of glimepiride and the decreased metabolic clearance may leads to decreased total clearance. The present investigations are in accordance with the earlier in vitro studies of boswellia metabolic inhibition on CYP2C9 enzyme in human liver microsomes [12].

In pharmacodynamic study, the mean serum glucose level and percentage glucose reduction of antihyperglycemic method of pretreated diabetic rats is shown in Table 3. The data reveals that there is a maximum reduction of serum glucose level in combination of BSE, BA with glimepiride pretreated groups (52.95\%, 53.04\%), when compared to standard (glimepiride, 50.07\%), BSE (34.66\%) and BA $(35.39 \%)$ alone pretreated groups at $6^{\text {th }} \mathrm{hr}$, respectively. The increase in hypoglycemic action of concomitant administration of glimepiride with BSE and BA was more in diabetic rats compared to alone treated drugs and with control group, which suggests the enhancement of glucose reduction capacity of glimepiride in diabetic rats along with boswellia.

In OGTT, administration of glucose load $(2.5 \mathrm{~g} / \mathrm{kg}, \mathrm{p} . \mathrm{o})$ increased serum glucose levels significantly $(\mathrm{p}<0.01)$ after $30 \mathrm{~min}$ of glucose loading in diabetic rats. Glimepiride, BSE and BA treatment alone or in combination produced significant $(\mathrm{p}<0.01)$ increase in glucose threshold within $30 \mathrm{~min}$ of glucose loading and the effects persisted till 120 min (Table 4).

In sub acute study, there was a gradual diminution in body weight of animals in diabetic control group. The animals of BSE, BA alone and their combination with glimepiride and standard drug treated groups showed a gradual and significant $(\mathrm{p}<0.01)$ increase in the body weight from 7 days onwards. The increase in the body weight was observed till the end of the study ( 28 days). The significant $(\mathrm{p}<0.01)$ effect of the combination and alone pretreated drugs on body weight of the animals was comparable to that of the standard drug, glimepiride at each time interval of the study (Figure 1). This significant improvement in body weight indicates the ability of combination of drugs and individual drugs to prevent loss of body weight in diabetic rats. It reveals that these drugs do not have any effect on degradation of depot fat to maintain the body weight [21].

The effect of the combination of BSE, BA with glimepiride in reducing the blood glucose levels was gradually increased and was maximum after 28 days $(\mathrm{P}<0.01)$, well comparable to that of the standard drug, BSE and BA alone pretreated groups (Figure 2). This phenomenon clearly indicates that these drugs in combination control the hyperglycemic state of type 2 diabetes more effectively than alone treated drugs.

There is a significant effect $(\mathrm{p}<0.01)$ of the combination of BSE

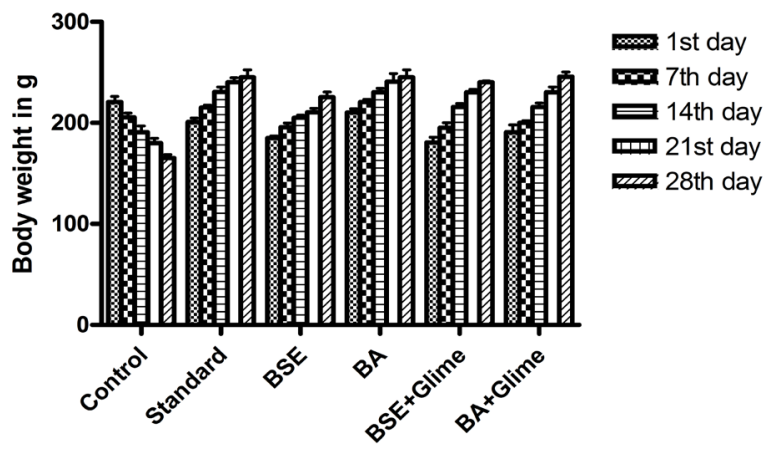

Figure 1: Effect of sub acute pretreatment of BSE, BA and glimepiride on body weights of STZ-induced diabetic rats.

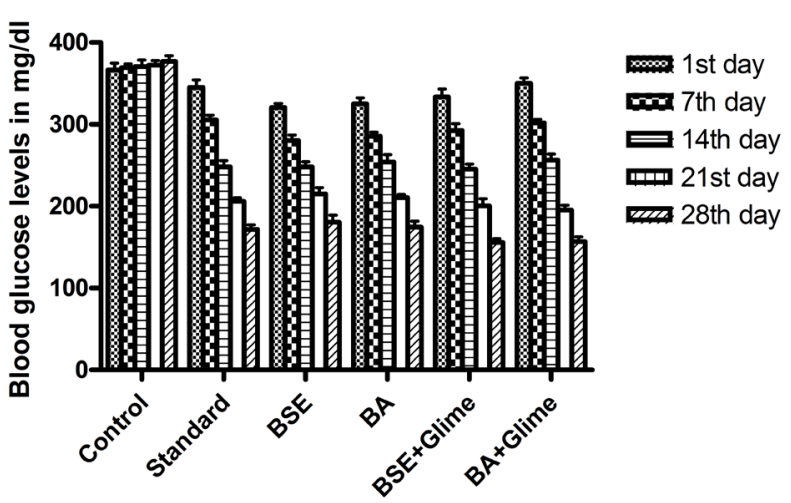

Figure 2: Effect of sub acute pretreatment of BSE, BA and glimepiride on blood glucose levels of STZ-induced diabetic rats.

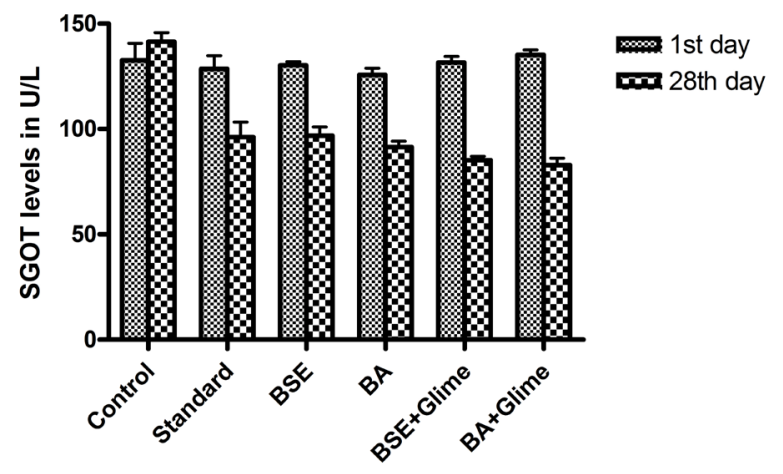

Figure 3: Effect of sub acute pretreatment of BSE, BA and glimepiride on SGOT levels of STZ-induced diabetic rats.

and BA with glimepiride in reducing serum GOT and GPT levels was maximum after 28 days showing $35.26 \%, 38.76 \%$ and $35.28 \%, 38.31 \%$ respectively and was well comparable to that of the standard drug, glimepiride (25.19\%, 30.84\%). Whereas in BSE and BA alone pretreated group also found maximum diminution in serum GOT and GPT levels after 28 days showing $25.65 \%$ and $27.29 \%$ and $25.87 \%, 26.48 \%$ (Figures 3 and 4). This significant $(\mathrm{p}<0.01)$ reduction in SGOT and SGPT levels further strengthens the antidiabetogenic effect of these drugs because increased gluconeogenesis and ketogenesis occur in diabetes, which may be due to high levels of SGOT and SGPT [22]. 


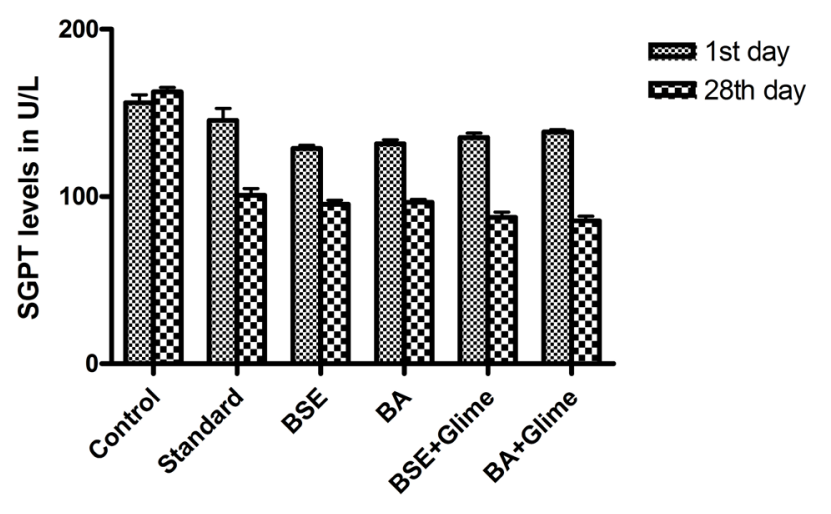

Figure 4: Effect of sub acute pretreatment of BSE, BA and glimepiride on SGPT levels of STZ-induced diabetic rats.

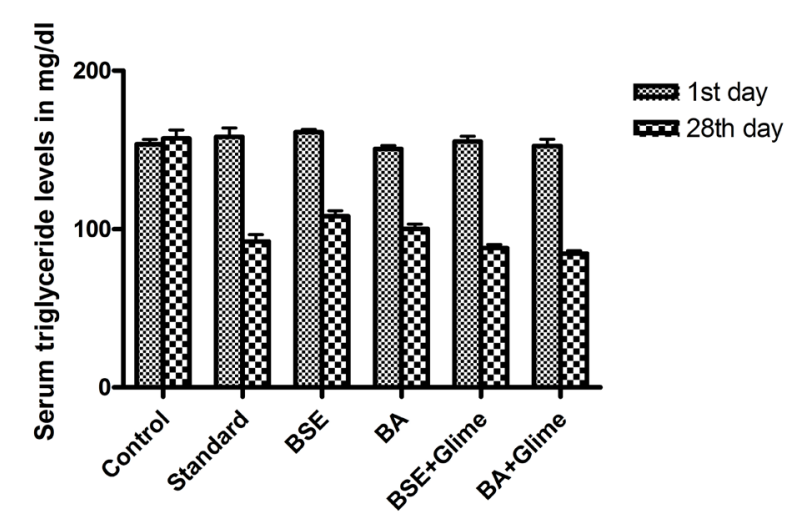

Figure 5: Effect of sub acute pretreatment of BSE, BA and glimepiride on serum triglyceride levels of STZ-induced diabetic rats.

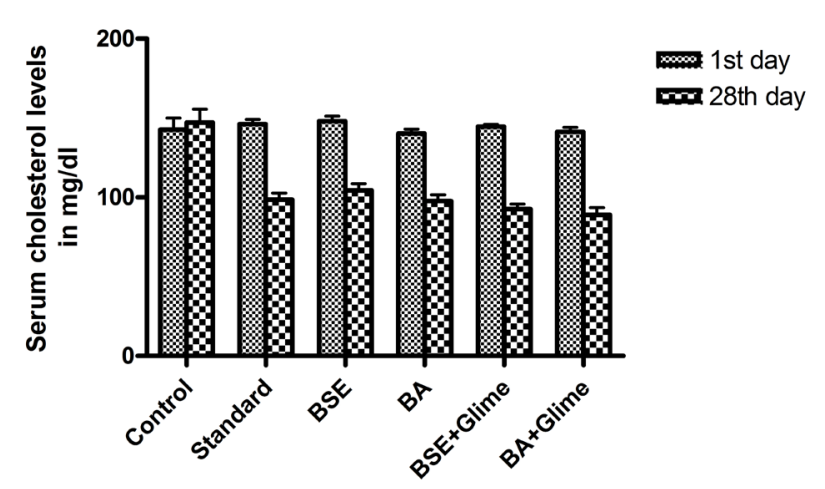

Figure 6: Effect of sub acute pretreatment of BSE, BA and glimepiride on serum cholesterol levels of STZ-induced diabetic rats.

The percent reduction in serum triglyceride levels of BSE and BA in combination with glimepiride treated groups was 43.31 and 44.63 , while it was 41.72 in standard group (glimepiride), 32.92 (BSE) and 33.51 (BA) alone pretreated groups (Figure 5). The percent reduction in serum cholesterol levels of BSE and BA in combination with glimepiride groups was $36.03 \%$ and $36.99 \%$, while it was $32.56 \%$ in standard group (glimepiride), BSE (29.51\%) and BA (30.29\%) alone treated groups (Figure 6). This phenomenon clearly indicates that these drugs in combination have more antihypertriglyceridemic and antihypercholesterolemic activity than alone pretreated groups and with control group.

The significant increasing effect $(\mathrm{p}<0.01)$ of the combination of BSE, $\mathrm{BA}$ with glimepiride groups on serum total protein levels was maximum after 28 days showing $52.63 \%$ and $53.66 \%$, was well comparable to that of the standard (51.1\%), BSE (37.1\%) and BA (38.7\%) alone pretreated groups (Figure 7). Further, the increased serum total protein level brought out by these drugs explains its antidiabetogenic effect as the reduction in protein level takes place in diabetes due to deficiency

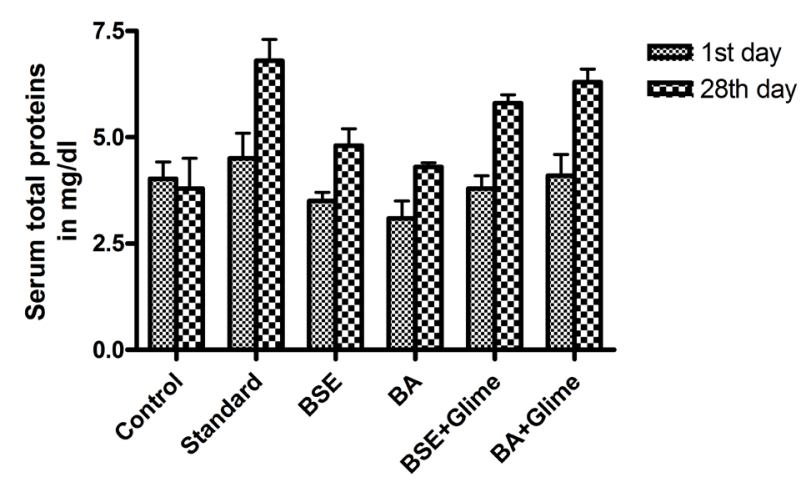

Figure 7: Effect of sub acute pretreatment of BSE, BA and glimepiride on serum total protein levels of STZ-induced diabetic rats.

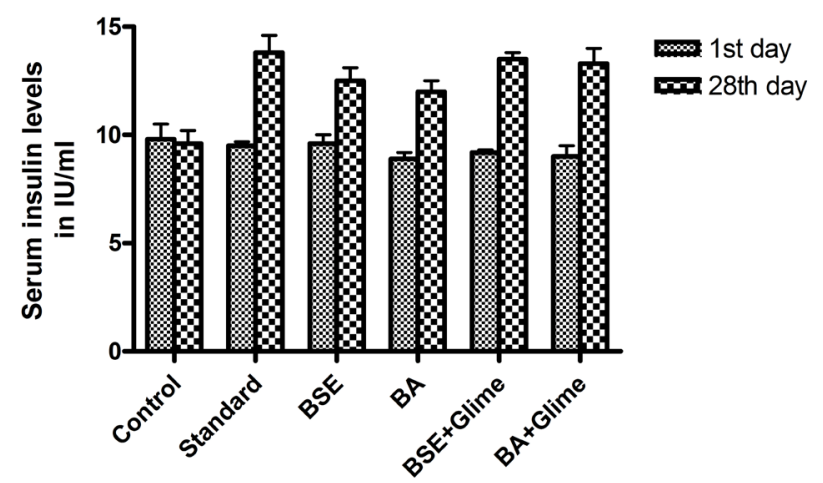

Figure 8: Effect of sub acute pretreatment of BSE, BA and glimepiride on serum insulin levels of STZ-induced diabetic rats.

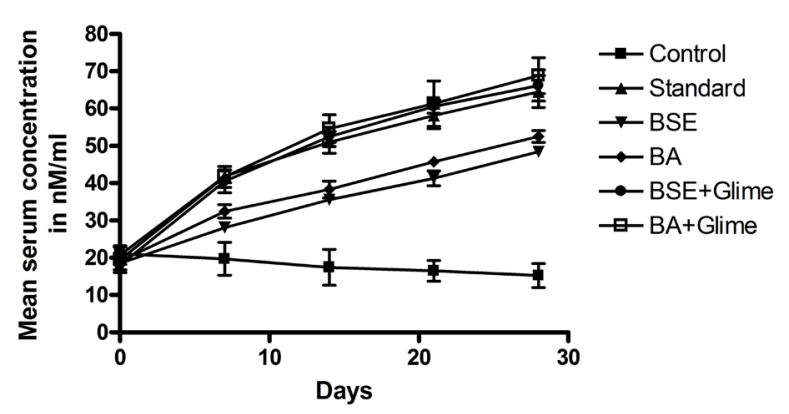

Figure 9: Effect of sub acute pretreatment of BSE, BA and glimepiride on total antioxidant status of STZ-induced diabetic rats. 


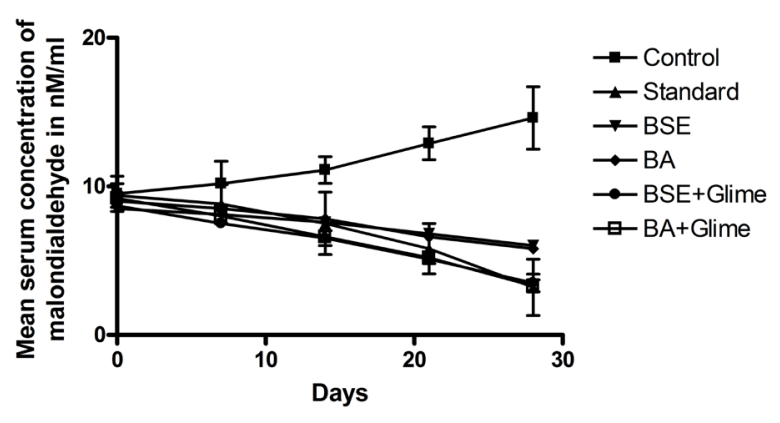

Figure 10: Effect of sub acute pretreatment of BSE, BA and glimepiride on lipid peroxide levels of STZ-induced diabetic rats.

of insulin, which stimulates uptake of aminoacids into muscle and increases protein synthesis [23].

The significant increasing effect $(\mathrm{p}<0.01)$ of the combination of BSE, BA with glimepiride groups on serum insulin levels was maximum after 28 days showing $46.74 \%$ and $47.78 \%$ was well comparable to that of the standard glimepiride (45.26\%), BSE (30.21\%) and BA $(34.83 \%)$ alone pretreated groups (Figure 8 ). This significant increase in serum insulin levels indicates that BSE or BA might have exhibited the antihyperglycemic effect like glimepiride, i.e., by insulin secretogogue activity [24].

The serum total antioxidant status and lipid peroxide levels of different pretreated groups in diabetic rats is shown in Figures 9 and 10. The combination of BSE, BA with glimepiride groups found gradually increased $(p<0.01)$ in total antioxidant status when compared with BSE, BA, glimepiride alone pretreated groups and with control group at all time intervals of the study. The lipid peroxide levels were found decreased significantly $(\mathrm{p}<0.01)$ in coadministration of BSE, BA with glimepiride groups when compared with BSE, BA and glimepiride alone pretreated groups and with control group at all time intervals of the study. This suggests that the combination of these drugs may stimulate the antioxidant mechanisms and interfere with PK and PD.

\section{Conclusion}

The present study indicated that BSE or BA affects the metabolism of glimepiride, possibly by the inhibition of CYP2C9. Combination of glimepiride with BSE or BA considerably enhances the glucoselowering effect of glimepiride. Hence, glimepiride doses may require special attention if used along with BSE or BA containing herbal preparations to avoid complications.

\section{Acknowledgement}

The authors are thankful to Dr. Reddy's laboratories, Hyderabad and Amsar Pvt. Ltd., Indore, India for the gift samples of glimepiride, gliclazide and Boswellia serrata standardized extract.

\section{References}

1. Kelly JP, Kaufman DW, Kelley K, Rosenberg L, Anderson TE, et al. (2005) Recent trends in use of herbal and other natural products. Arch Intern Med 165: 281-286.

2. Brazier NC, Levine MA (2003) Drug-herb interaction among commonly used conventional medicines: a compendium for health care professionals. Am J Ther 10: 163-169.

3. Badole SL, Patel NM, Thakurdesai PA, Bodhankar SL (2008) Interaction of Aqueous Extract of Pleurotus pulmonarius (Fr.) Quel-Champ. with Glyburide in Alloxan Induced Diabetic Mice. Evid Based Complement Alternat Med 5: 159 164.
4. Fakeye TO, Oladipupo T, Showande O, Ogunremi Y (2007) Effects of coadministration of extract of Carica papaya Linn (Cariaceae) on activity of two oral hypoglycemic agents. Trop J Pharm Res 6: 671-678

5. Prakash Paranjpe (2005) Indian Medicinal Plants-Forgotten Healers: A Guide to Ayurvedic Herbal Medicine. Chaukhamba Sanskrit Pratishth.

6. Gayathri B, Manjula N, Vinaykumar KS, Lakshmi BS, Balakrishnan A (2007) Pure compound from Boswellia serrata extract exhibits anti-inflammatory property in human PBMCs and mouse macrophages through inhibition of TNFalpha, IL-1beta, NO and MAP kinases. Int Immunopharmacol 7: 473-482.

7. Hostanska K, Daum G, Saller R (2002) Cytostatic and apoptosis-inducing activity of boswellic acids toward malignant cell lines in vitro. Anticancer Res 2: 2853-2862.

8. Sharma ML, Bani S, Singh GB (1989) Anti-arthritic activity of boswellic acids in bovine serum albumin (BSA) - induced arthritis. Int J Immunopharmacol 11 : 647-652.

9. Ammon HP (2010) Modulation of the immune system by Boswellia serrata extracts and boswellic acids. Phytomedicine 17: 862-867

10. Shehata AM, Quintanilla-Fend L, Bettio S, Singh CB, Ammon HP (2011) Prevention of multiple low-dose streptozotocin (MLD-STZ) diabetes in mice by an extract from gum resin of Boswellia serrata (BE). Phytomedicine 18: 10371044.

11. Menon MK, Kar A (1971) Analgesic and psychopharmacological effects of the gum resin of Boswellia serrata. Planta Med 19: 333-341.

12. Frank A, Unger M (2006) Analysis of frankincense from various Boswellia species with inhibitory activity on human drug metabolizing cytochrome P450 enzymes using liquid chromatography mass spectrometry after automated online extraction. J Chromatogr A 1112: 255-262.

13. Rosskamp R, Wernicke-Panten K, Draeger E (1996) Clinical profile of the nove sulphonylurea glimepiride. Diabetes Res Clin Pract 31 Suppl: S33-42.

14. RILEY V (1960) Adaptation of orbital bleeding technic to rapid serial blood studies. Proc Soc Exp Biol Med 104: 751-754.

15. Tuitoek PJ, Ziari S, Tsin AT, Rajotte RV, Suh M, et al. (1996) Streptozotocininduced diabetes in rats is associated with impaired metabolic availability of vitamin A (retinol). Br J Nutr 75: 615-622.

16. Sujatha S, Sandhya Rani T, Veeresham C (2011) Determination of glimepiride in rat serum by RP-HPLC method. Am J Analy Chem 2: 160-165.

17. Trinder $P$ (1969) Determination of blood glucose using 4-amino phenazone as oxygen acceptor. J Clin Pathol 22: 246.

18. Syed mansoor A, Vrushabendra swamy BM, Dhanapal PGR, Chandrashekara VM (2005) Antidiabetic activity of Terminalia catappa Linn. leaf extracts in alloxan-induced diabetic rats. Iranian J Pharmacol Ther 4: 36-39.

19. Reddy YN, Murthy SV, Krishna DR, Prabhakar MC (2004) Role of free radicals and antioxidants in tuberculosis patients. Indian J Tuberc 51: 213-218.

20. Ohkawa H, Ohishi N, Yagi K (1979) Assay for lipid peroxides in animal tissues by Thiobarbituric acid reaction. Anal Biochem 95: 351-358.

21. Chakrabarti S, Biswas TK, Seal T, Rokeya B, Ali L, et al. (2005) Antidiabetic activity of Caesalpinia bonducella $F$. in chronic type 2 diabetic model in LongEvans rats and evaluation of insulin secretagogue property of its fractions on isolated islets. J Ethnopharmacol 97: 117-122.

22. Felig P, Marliss E, Ohman JL, Cahill CF Jr (1970) Plasma amino acid levels in diabetic ketoacidosis. Diabetes 19: 727-728.

23. Chakrabarti R, Rajagopalan R (2002) Diabetes and insulin resistance associated disorders: disease and the therapy. Curr Sci 83: 1533-1538.

24. Abdel-Zaher AO, Salim SY, Assaf MH, Abdel-Hady RH (2005) Antidiabetic activity and toxicity of Zizyphus spina-christi leaves. J Ethnopharmacol 101 129-138. 